\title{
Parenting Patterns for Developing Early Childhood Multiple Intelligences: A Study of Phenomenology in Indonesia
}

\author{
M. Fadlillah", ${ }^{1, *}$ Rochmat Wahab ${ }^{2}$, Yulia Ayriza ${ }^{3}$, Lailatu Rohmah $^{3}$, Erif Ahdhianto ${ }^{4}$ \\ ${ }^{1}$ Department of Early Childhood Education, Universitas Muhammadiyah Ponorogo, Indonesia \\ ${ }^{2}$ Department of Education Science, Universitas Negeri Yogyakarta, Indonesia \\ ${ }^{3}$ Department of Early Childhood Islamic Education, UIN Sunan Kalijaga Yogyakarta, Indonesia \\ ${ }^{4}$ Department of Elementary School Teacher Education, Universitas Nusantara PGRI Kediri, Indonesia
}

Received May 9, 2020; Revised September 11, 2020; Accepted September 29, 2020

\section{Cite This Paper in the following Citation Styles}

(a): [1] M. Fadlillah, Rochmat Wahab, Yulia Ayriza, Lailatu Rohmah, Erif Ahdhianto , "Parenting Patterns for Developing Early Childhood Multiple Intelligences: A Study of Phenomenology in Indonesia," Universal Journal of Educational Research, Vol. 8, No. 11B, pp. 5704 - 5715, 2020. DOI: 10.13189/ujer.2020.082204.

(b): M. Fadlillah, Rochmat Wahab, Yulia Ayriza, Lailatu Rohmah, Erif Ahdhianto (2020). Parenting Patterns for Developing Early Childhood Multiple Intelligences: A Study of Phenomenology in Indonesia. Universal Journal of Educational Research, 8(11B), 5704 - 5715. DOI: 10.13189/ujer.2020.082204.

Copyright $\mathrm{C} 2020$ by authors, all rights reserved. Authors agree that this article remains permanently open access under the terms of the Creative Commons Attribution License 4.0 International License

\begin{abstract}
The potential of multiple intelligences of early childhood possessed from birth will be able to develop optimally when they get the right parenting patterns from their parents. Unfortunately, there are still many parents, especially in Java who do not understand it, so parenting tends to be careless. On the other hand, related research is still very limited. This research aimed to explore parenting patterns by parents in developing multiple intelligences in early childhood. This research used qualitative methods with a phenomelogical approach to uncover this phenomenon. Data collection was carried out by in-depth and open interviews with three parents who have early childhood with excellence and achievements in the field of multiple intelligences. Data analysis used a phenomenological qualitative analysis. This research indicates that there are three main themes of parenting patterns, namely: 1) identification of children's interests and talents: done by parents intensively by observing activities that are preferred and become children's excellence intensively; 2) the demandingness and responsiveness of parents in developing children's multiple intelligences: Parents' high demandingness and responsiveness can develop early childhood multiple intelligences; and 3) the development and stimulation of multiple intelligences: parents stimulate the children's multiple intelligences talents by having children take a
\end{abstract}

course and various competition activities that are appropriate to their abilities. In short, our research shows that balanced demands and responses from parents are required so that the multiple intelligences can develop optimally so that they will be able to make the expected abilities and achievements.

Keywords Parenting, Interests and Talents, Multiple Intelligences, Early Childhood

\section{Introduction}

Children are a mandate from God that must be guarded and cared for as well as possible. Since birth, children have been equipped with various potentials that are ready to be stimulated and developed by their environment. The United Nations Education Scientific and Cultural Organization explains that children from birth to the age of 8 years are referred to as early children who have very rapid brain growth and development so that they need stimulation and guidance from their environment (UNESCO, 2017). By the time a child is 4 years old, half $(50 \%)$ of his/her intellectual potential has been formed so that if at the age of 0-4 years a child does not get the right 
brain stimulation, the brain's performance cannot develop optimally (Chatib, 2016). The intellectual potential develops reaching $80 \%$ at the age of 8 years, and reaches its culmination point $(100 \%)$ at the age of 18 years (Permono, 2013). In addition, children are the next generation of parents in the future. Lerner, Sparks and McCubbin mention that children represent 100 percent of human in the future and social capital on which the state depends (Brooks, 2011). According to Law No. 23 of 2002 concerning Child Protection, it is stated that children as budding, potential, and next generation of young people aspiring to the national struggle have a particular strategic role, characteristics and traits so that they must be protected from all forms of inhuman treatment which results in violations of human rights (REPUBLIK INDONESIA, 2002). Every child has the right to survival, growth, and development, and is entitled to protection from violence and discrimination (REPUBLIK INDONESIA, 1945). Once the importance of early childhood, every child must be given the best care and therefore his potential can develop optimally. Children must get good stimulation from the environment. For children, the environment is very influential on their beliefs, behavior, and achievements (Morrison, 2008). The experience gained by the child will determine his future.

Parents are the closest environment to children. Parents are obliged to care for, maintain, raise and provide the best education for children. In children, there is a 'potential' treasure that must be known by parents (Chatib, 2016). The form of potential is in the form of multiple intelligences (Hanafin, 2014). All humans do not only have one single intelligence, but several intelligences (Gardner, 2006). That is, each child may have some intelligences, even if only one or two are the most dominant. If the multiple intelligences are well facilitated, it can deliver positive change for the children's life in the future. Therefore, parents must provide quality parenting so that the children's multiple intelligences can develop optimally.

Unfortunately, understanding of parenting that can develop children's multiple intelligences is still limited. Many parents still think that intelligence is only academic, whereas other types of intelligence tend to be ruled out. The results of a survey of the Indonesian Child Protection Commission (KPAI) showed that $66.4 \%$ of fathers and $71 \%$ of mothers from 800 family respondents imitated the care taken by their parents previously only prioritizing academic development (Sasongko, 2015). This type of parenting this is not appropriate for early childhood, because it can inhibit the other intelligences. Royanto explains that children aged 7-12 years have great interests and talents in cognitive, social, emotional and physical aspects (Khoiri, 2016). Gardner mentions that there are eight intelligences that are possible to be developed in children, including: linguistics, logic-mathematics, kinesthetic, visual-spatial, musical, interpersonal, and naturalist (Arsmtrong, 2009; Gardner, 2006). These multiple intelligences can develop well when stimulated since early childhood through quality parenting according to their needs and characteristics.

Violence occurring against children in Indonesia according to KPAI is due to poor parental care (Sasongko, 2015). Another opinion states that some children in Indonesia experience wrong treatment of parents (Khoiri, 2016). In 2018, it was stated that there had been 23 cases of child abuse occurring in the family, where the highest violence was committed by biological mothers by $44 \%$, fathers $18 \%, 22 \%$ of mothers and stepfathers, $8 \%$ of caregivers, and $8 \%$ of caregivers (Sulistyawati, 2018). Those various parenting problems cause the children's potential not to develop, even death. Therefore, in order to develop the interests, talents, and intelligence of young children optimally, they need proper parenting from parents. Various studies show that parenting style greatly influences children's behavior and achievement (Baumrind, 2005).

Parenting style of parents greatly influences the development of children's intelligence. Parents' attitudes and styles in parenting have a strong impact on children's achievement in school (Kordi, 2010). In this context, the most influential parenting style on children's achievement is authoritative (Dehyadegary, 2012). Between father and mother, the most dominant in parenting is mother. A mother plays an important role that greatly influences a person's social, emotional and cognitive growth and development (Hidalgo, 2016). Therefore, this research aimed to reveal parenting experiences of parents, especially biological mothers of children in developing multiple intelligences of early childhood. These experiences are expected to produce the right parenting pattern to develop children's multiple intelligences.

The development of multiple intelligences in early childhood is strongly influenced by the type and parenting style of parents. Parenting quality shown by parents has a significant positive relationship towards children's development (Dexter, 2014). Multiple intelligences of children can develop optimally when getting the right stimulation according to their needs. The essence of multiple intelligences is to appreciate the uniqueness of each individual (Agustin, 2013). Every child is unique and requires special treatment according to their needs (Hidalgo, 2016). The task of parents is only to help find it, and then develop it so that the child reaches the best condition (Chatib, 2016). Parents must support and facilitate each child's uniqueness well. Child development actually begins in the family system (Morrison, 2012). Therefore, various experiences and guidance given by parents can help the development of a child's multiple intelligences.

\section{Theoretical Framework}

There are two typologies that influence parenting style 
of parents, namely demandingness and responsiveness (Baumrind, 1991). Demandingness refers to claims made by parents to children to be integrated into society through regulation of behavior, direct confrontation, and demandingness for maturity and supervision of children's activities, whereas responsiveness refers to the actions of parents who support their children's actions and approve their requests (Baumrind, 2005). Demandingness is characterized by parental demands on the child's behavior or actions, while responsiveness is characterized by the warm attitude of the parents towards the child (Baumrind, 2010). From this typology, four parenting styles are born and become the reference of most scientists in the world, namely: authoritarian, authoritative, permissive, neglecting (Baumrind, 1991; Holden, 2010).

Parents' demandingness and expectations of children's talents can also influence parenting styles. This parenting style really determines the form of treatment of parents to children. As explained by Baumrind that parenting style is strongly influenced by two dimensions, namely demandingness and responsiveness (Baumrind, 2005). Spera explains that the parenting style emphasizes the response parents give to their children and the methods used by parents to demand obedience from their children (Dehyadegary, 2012). Based on this explanation, it can be understood that the demandingness and expectations of parents in parenting are very important and must be done by parents so that children's talents can be developed optimally.

The demandingness of parents is in line with the purpose of parenting itself. Parenting is intended to look after and treat children so that their abilities can develop properly. Parenting is a form of parental control over children's behavior (Baumrind, 1966). Parents play the role of guiding, regulating, controlling, and shaping children as they wish. In this context, parents must be able to know and understand the abilities and development of children, and therefore they can fulfill everything the child needs themselves.

Correspondingly, Santrock explains that parenting is a way of nurturing applied by parents so that children become educated and trained (Santrock, 2009). Parents in caring for their children aim to educate and train so that the various potentials of the child can develop optimally. As explained that care is taken in order to improve and develop children's abilities (Lestari, 2016).

Parents' goals and motivation are very important in parenting. The demandingness determined greatly determines the form of parental treatment of children. Parents will be willing to do anything to realize the desired goals. The main motive of parents in parenting is to stimulate the child's growth and development in order to develop optimally. In line with that, LeVine as quoted that the universal goals of parenting include: ensuring physical health and safety; developing behavioral capacity to protect oneself with economic considerations; and fulfillment of behavioral capacity to maximize cultural values, for example morality, glory, achievement (Berns, 2010).

The National Institute of Child Health and Development explains that good parental care, affection and warmth, and positive stimuli that are age-appropriate from birth onwards make a big difference in cognitive development for a lifetime (Morrison, 2008). According to Bornstein and Landsford, parents play a very important role during the first years of children's lives when they experience rapid development in language, cognitive, and social-emotional (Li, 2017). Parenting can determine and assist children's development, such as language, cognitive, and social-emotional. Parenting is done in an effort to provide responsibility and attention which includes affection and ongoing relationships with children; material needs such as food, clothing, and shelter; access to medical needs; responsible discipline, avoidance of accidents, excessive criticism and dangerous physical punishment; intellectual and moral education; preparation to be responsible as an adult; and responsible for children's actions to the wider community (Brooks, 2011).

Second, responsiveness is a form of parental commitment in supporting the abilities or talents of children. Responsiveness refers to the extent to which parents deliberately foster individuality, self-regulation, and self-affirmation in a balanced, supportive, and agreeing way to the special needs and demandingness of children (Baumrind, 1991). Parental support and approval can have a positive influence on the development of children's talents. Parental support can promote children's talent (Kiewra, 2014). By providing maximum support, children's talents can develop optimally.

Responsiveness and commitment in parenting is a picture of parental support for children's talents. Parental support is important in developing children's abilities in multiple intelligences. Support provided by parents can foster and build children's confidence. A supportive environment can promote mental health and strengthen child-centered activities (Morrison, 2015). The results of the regression analysis revealed that parental support and involvement positively predicted the academic self-efficacy and self-esteem of children. By getting support from parents, children feel they are getting attention, affection, and care. In addition, parental support is considered a form of approval and appreciation for their abilities.

Parental support in developing the abilities of their children can be in the form of moral and material support. Moral support is a support related to children's mental and feelings. For example, this moral support is to take and accompany children during tutoring or competitions and give encouragement and praise to children. A supportive environment can be done by parents to spend time with children, interact pleasantly with children, and support and help children (Morrison, 2015). The involvement of 
parents in their children's learning process provides many opportunities for success, such as improving morals and attitudes, academic achievement in all fields, as well as social attitudes and adjustments (Sapungan, 2014).

Material support is a support related to meeting the physical needs of children, such as costs, facilitating children's activities, and giving rewards to the achievements that have been achieved by children. Various material supports are intended to provide stimuli to children, so that they will more enthusiastic and improve their achievement. As explained by Skinner in his theory operant conditioning. In this theory, it is underlined that there is a relationship between stimulus, reinforcement, and response (Salkind, 2004). The response that arises from the stimulus provided can be continually improved through the provision of reinforcement. That is, when children are given positive stimulation as well as reinforcement, it can also bring positive responses as desired. Watson as Pavlov's follower explains that individual behavior can be fully formed in accordance with what the environment desires (Salkind, 2004). Therefore, by providing stimulus and reinforcement in the form of materials and various prizes, it is expected that children can show their abilities more optimally.

In a different theory, Maslow revealed that a person can achieve self-actualization if the basic needs of children are met (Morrison, 2015). These basic needs can be physical or psychological. Children cannot demonstrate and maximize their abilities if their basic needs have not been met. For Maslow, the basic needs of children are essential in order to achieve all that they are able to achieve (Morrison, 2015). Moral and material support is one form of meeting the basic needs of children. By respecting and facilitating the needs of children in developing their talents, it means that they have supported the achievement of children's self-actualization.

To achieve self-actualization a child must first meet the five basic needs underneath. Self-actualization is characterized by children able to maximize their potential, promote growth and development, and can encourage children to do their best (Morrison, 2015). Children can achieve or show and maximize their abilities when they get support from parents and their immediate environment. Support in this context is to meet the five basic needs of children.

Five basic needs that must be met according to Maslow are (1) the needs of the essentials of life; (2) security and safety: (3) ownership and love: (4) achievement and prestige; and (5) aesthetic needs (Morrison, 2015). The essential needs of life (physiological) are the children's physical needs, such as food, water and air. Safety and security needs are children's needs related to security, free from fear, and stability. Ownership and love needs are children's needs related to love, acceptance and appreciation. Achievement needs are children's needs related to approval, recognition and appreciation, including facilitation of children's activities. Finally, aesthetic needs are children's needs related to beauty and order. Support given by parents, including moral and material is an effort to meet the basic needs of children. It is expected that by these various supports, children can achieve self-actualization by being able to achieve according to their respective potential.

Demandingness and responsiveness of parents to children are closely related. Demandingness is a picture of the form of parental treatment that leads to the determination of behavioral regulations, demands for maturity, and supervision of the activities of their children (Baumrind, 1991). Parents with this approach have high expectations of the child's achievements. To realize these expectations, parents have rules that must be obeyed and followed by their children. Responsiveness is a form of parental treatment that is characterized by emotional support, warmth, as well as actions to approve and meet the needs of children (Baumrind, 2010). Parents are very caring and loving towards the abilities of children. What children wants and needs are met by their parents.

Demandingness and responsiveness of parents determine the parenting style of the parents. According to Shaffer as quoted that parents who have high demandingness and responsiveness are more inclined towards the authoritative style (Lestari, 2016). Meanwhile, low demandingness and responsiveness of parents are more likely towards an uninvolved style. The high demandingness of parents which are not accompanied by high responsiveness is more likely to lead to an authoritarian style. Conversely, high responsiveness of parents which are not accompanied by high demandingness are more likely to lead to permissive styles. Based on the theoretical framework, it can be understood that child's multiple intelligences can develop when parents provide positive and balanced demands and responses. Parents who are sensitive and concerned about the child's multiple intelligences can take him to achieve a significant achievement. For this reason, parents must be able to become good caregivers for the development of children's multiple intelligences in the next period.

\section{Materials and Methods}

This research aimed to produce and describe parenting patterns to develop early childhood multiple intelligences. This research used a qualitative method with a phenomenological approach. The reason for using qualitative methods is because this research is a study of social situations and studies the behavior of certain individuals (Creswell, 2008; Sugiyono, 2011). To be able to explore the experiences of each individual and understand the meaning of the events she experienced, the phenomenological approach was used.

In this research, the data sought were in the form of 
views, understanding, and experiences of parents in caring for and developing children's multiple intelligences. Various phenomena experienced by parents can be revealed and obtain a picture of the real meaning in accordance with the views and experiences of the resource persons when done with a phenomenological approach. Phenomenology studies are considered very appropriate to describe the general meaning of a number of individuals on their various life experiences in certain situations (Bogdan, 1982; Creswell, 2008).

The data collection technique was carried out by in-depth and open-ended interviews with three parents of young children who have achievements and excellence in multiple intelligences. They are parents of child A (R1), parents of child B (R2), and parents of child C (R3). Child A has superiority and achievement in the field of kinesthetic and musical intelligences. His achievements included winning awards in the field of fashion shows and dancing for 78 times and singing for 36 times. Child B has advantages and achievements in the fields of visual-spatial intelligence, logic-mathematics, and linguistics. His achievements were winning coloring competitions for 72 times, mathematics for 10 times, and memorization for 11 times. Child $\mathrm{C}$ has advantages and achievements in the fields of visual-spatial and logic-mathematics intelligences. His achievements included winning awards in coloring competitions for 63 times, mathematics for 4 times and being class champion for 2 times.

The interview participants were determined through a purposive sampling technique. The three parents in this research were represented by biological mothers. This is because biological mothers are believed to be more dominant in developing children's intelligences. Criteria in the selection of participants included parents must have early childhood who have superiority in multiple intelligences at least two intelligences. This can be proven by the high achievement in each intelligence they have. To find out the achievements of the children's achievements, the first thing to do was to visit and observe schools to look for data on the children having achievement. After getting the data needed the researcher asked for help from the teacher to have an appointment meeting with the child's parents. The next communication was done by using WhatsApp, including asking parents' willingness to become research participants.

Data analysis in this research used inductive analysis with phenomenological analysis model from Stevick, Colaizzi and Keen. This analysis started from transcribing all the results of the interview, inventorying important statements, classifying important statements that fit the theme, constructing the meaning and essence of the participants' experiences, and ending with compiling a research report (Hasbiansyah, 2008). By using this analysis, a meaning of events experienced by individuals can be taken thoroughly.

\section{Findings and Discussion}

The description of the results of research on parenting patterns to develop multiple intelligences in early childhood revealed factually the parenting experiences of three parents. The first participant (R1) is the parent of child A who has excellence in musical intelligence and kinesthetic. These musical and kinesthetic abilities are characterized by the skills of child A in singing, fashion shows, and dancing. The second participant (R2) is the parent of child B who has an excellence in the fields of visual spatial intelligence and mathematical logic. This is evidenced by the ability of child $\mathrm{B}$ in coloring and proficiency in science and calculation. The third participant (R3) is the parent of child C who has an excellence in the field of spatial visual intelligence. This ability is characterized by the child's skills in coloring. The three participants were interviewed in depth and openly about their parenting experiences in stimulating and developing children's multiple intelligences. Based on interviews with participants, this research has revealed important experiences regarding parenting patterns which are grouped into three main themes, namely: 1) identification of children's interests and talents; 2) the demandingness and responsiveness of parents in developing children's multiple intelligences; and 3) The development and stimulation of multiple intelligences. The results of the research are explained as follows:

\section{Theme 1. Identification of children's interests and talents}

The participants revealed that the interests and talents of their children had begun to appear since early childhood. These interests and talents are known by parents by looking at children's interests and excellence. Interest here is interpreted as an activity that children like to do, while excellence is something that becomes the strength of children, especially related to the talents or abilities of children. The results of the interviews with each participant indicate:

Since the age of three, my child has loved. Fashion and dancing began to appear when he was four years old. When he was little he loved singing and dancing in front of television while holding a loudspeaker. I once took him to participate in a competition at that time but he did not win (R1).

Similar to R1, R2 gave the following statement: My child's abilities began to appear before entering the playgroup, especially in coloring. Since childhood, he likes to doodle and play crayons on drawing paper for almost hours and have fun by himself. Then, I guided and practiced with self-taught until finally he could (R2).

R3 was slightly different from R1 and R2. She said: 
At first I did not yet know the ability of my child. At that time in the playgroup my child joined a coloring contest by the school and won third place. Then, I offered him to take coloring lessons and he said yes. From there, it appeared that my child liked and had the ability to color (R3).

Based on this explanation, it can be understood that each parent has almost the same parenting experience. In identifying the interests and talents of children, there are similarities between the three parents. Some similarities in identifying these interests and talents are: 1) looking intensively at children's interests and preferences and 2) seeing the excellence of children's abilities/intelligence. In these two ways, parents can find out their children's interests and talents in an effort to provide appropriate stimulation. Identification of children's interests and talents of the three participants can be seen in table 1 .

Identification of children's interests and talents is very important. It is because to be able to develop children's multiple intelligences, parents must first be able to identify their interests and talents. By knowing the interests and talents of children, parents will be easier to develop the abilities of their children. Identification of interests and talents is intended as an effort to find out the potential that exists in the child. A parenting expert named Nikki Bush said that every child has something that becomes their talent, and the task of parents is to help find that talent so they can develop and use it for the greater good (Ramphele, 2017). Correspondingly, Robinson revealed that everyone has talent in a particular field and that talent is likely to develop when parents can find and facilitate it (Kiewra, 2014). According to Sternberg, a child whose talent is identified will have a better chance of success than his friends whose talent is not identified (Tiel, 2015). If a child's ability is not identified and supported, the child can be depressed and show behavior that leads to a loss of potential for the individual and society as a whole (Morawska, 2019). Based on this explanation, it can be understood that parents must be able to identify the interests and talents of children in order to develop them.

Identifying children's talents can be done by parents in various ways, starting from testing the talent/intelligence of children to the direct observation of children's interests and abilities. Interests and talents of children can be known by continuously observing the activities that are liked by children. Children's preferences related to this talent are different from a temporary like, but the love that is continuous and able to produce a work, and quickly grasp and understand new things that are given to them (Chatib, 2016). Early childhood identification can be done through signals of growth and development, personality and characteristic behavior, as well as special intelligence signals in the form of academic achievement and other fields (Tiel, 2015). Based on data from the research results, it indicates that parents know the interests and talents of their children by recognizing the activities they like and observe the strengths/excellence of children in certain fields. This is done intensively by parents since the age of the child is still in the playgroup that children have an interest in what they do.

Table 1. Parents' Parenting experience in identifying the interests and talents of children

\begin{tabular}{llll}
\hline \multirow{2}{*}{ Forms of Experience } & \multicolumn{1}{c}{ R1 } & \multicolumn{1}{c}{ Names of Participants } & \multicolumn{1}{c}{$\mathbf{R 2}$} \\
\cline { 2 - 4 } & $\begin{array}{l}\text { Recognizing the child's interest, } \\
\text { namely: playing a microphone } \\
\text { while dancing in front of the }\end{array}$ & $\begin{array}{l}\text { Recognizing the child's interest, } \\
\text { namely: scribbling on paper for } \\
\text { hours. }\end{array}$ & $\begin{array}{l}\text { Recognizing the child's interest, } \\
\text { namely: being interested in } \\
\text { coloring since in the playgroup. }\end{array}$ \\
\hline $\begin{array}{l}\text { Identification of interests and } \\
\text { talents of multiple intelligences } \\
\text { Recognizing the excellence of } \\
\text { children, namely: being good at } \\
\text { singing, fashion shows, and } \\
\text { dancing. }\end{array}$ & $\begin{array}{l}\text { children's abilities, namely: } \\
\text { adepting at coloring, science, } \\
\text { mathematics, } \\
\text { reciting/memorizing Quran. }\end{array}$ & $\begin{array}{l}\text { Recognizing the excellence of } \\
\text { adepting at abilities, namely: } \\
\text { mathematics. }\end{array}$ \\
\hline
\end{tabular}


Theme 2. The demandingness and responsiveness of parents in developing children's multiple intelligences

The participants explained that they have very high demandingness and expectations for children's multiple intelligences. Their demandingness is marked by the desire of parents to develop their children's talents and get many achievements in the form of trophies and awards. R1 gave the following statement:

My child shows a talent. Therefore, I really want this child's talent to develop so that he can achieve and win many championships. That is the reason I take him for a training to develop that ability (R1).

In line with the description of R1, R2 and R3 also revealed that:

My child participates in various activities in order to learn and develop his full potential. In addition, my son wins a competition, gets a lot of experiences, and certainly has a brave mentality (R2).

My demand and hope for my child's talents is to develop his abilities and win many competitions. In addition, the most important thing is to have friends and be brave, because at first my child was very quiet (R3).

Based on this information, the forms of demandingness and expectations of each participant towards children's talents are generally the same, both R1, R2, and R3. The demandingness and expectations include: 1) children's talents can develop optimally; 2) having a brave mentality; 3 ) the insight and interaction of children increase; and 4) getting a lot of achievements. These demands are the expectations of each parent of the child's multiple intelligences.

As for the responsiveness, the participants explained that their commitment to children's multiple intelligences was to provide full support in various ways. This support is realized by always providing time and various facilities for their children so that children's talents can develop. R1 gave the following statement:

Almost every day, I take my child to school, take course, and participate in various competitions. When he takes course and competitions I always accompany him to finish for hours. That's all I do for my child, even though sometimes I feel tired. But for my child, all I do with pleasure. Moreover, it's my own child, I enjoy it very much (R1).

To provide facilities and meet the needs of R1's child, it also costs a lot, especially tuition fees, participating in competitions, and renting costumes for dancing or fashion shows. R1 gave statement as follows:

The cost that I have to spend to develop my child's abilities consists of the cost of singing lessons $\mathrm{Rp}$ 50,000 (fifty thousand Rupiah) per hour. Sometimes there are 2-3 times in a week. Then for fashion shows lessons, it takes Rp 200,000 (two hundred thousand rupiah) every month. For dance lessons, it costs $\mathrm{Rp}$ 60,000 (sixty thousand Rupiah) every month, not to mention the cost of the competition and costume rental. Usually for each competition, the registration fee is Rp 50,000 (fifty thousand Rupiah) but it also depends on the organizer. For costume rental, I usually find a cheaper one (R1).

Similarly, R2 revealed that she always fully supports what her child wants, especially related to the development of their talents. In addition to taking time to accompany children for learning and practicing, R2 also facilitates all children's needs. For example, finding material for her child's learning from YouTube and provides equipment to color. It is stated as follows:

The support that I provide which clearly facilitates, for example, coloring requires some tools meaning that I have to find them. Then, I try to make time with children, sometimes giving companion when he participates in competition from morning to evening. In addition, in order to give supports so the child gets excited, I reward him his favorite thing (R2).

Like R1 and R2, R3 also expressed the same thing, which always fully supports the interests and talents of her child as the following statement:

Every time my child goes to school and takes coloring lessons, Jarimatika, and English, I always take and accompany him. It becomes my daily activities. Not to mention that I must accompany him for hours from morning to evening. To keep my child excited to learn and practice, I buy equipment that he likes. Sometimes if he asks for a reward, I realize it (R3).

Based on these explanations, it shows that there are similarities in the form of responsiveness and commitment of parents in developing children's multiple intelligences. The responsiveness and commitment shown by them become one form of concern for children's development. Some forms of responsiveness and commitment from parents to the child's talent, include: 1) making time with the child; 2) providing motivation; 3) giving praise and rewards; and 4) facilitating children's needs. The demandingness and responsiveness of parents can be seen in table 2 . 
Table 2. Parental demandingness and responsiveness in developing children's multiple intelligences

\begin{tabular}{|c|c|c|c|c|c|}
\hline \multirow{2}{*}{ Forms of Experience } & \multicolumn{5}{|c|}{ Names of Participants } \\
\hline & & $\mathbf{R} 1$ & & $\mathbf{R 2}$ & $\mathbf{R 3}$ \\
\hline $\begin{array}{l}\text { Parents' } \\
\text { demandingness and } \\
\text { expectations for the } \\
\text { children's multiple } \\
\text { intelligences talents. }\end{array}$ & $\begin{array}{l}1 . \\
2 .\end{array}$ & $\begin{array}{l}\text { The child's talent develops. } \\
\text { Children have many friends } \\
\text { and relationships. } \\
\text { Winning trophies/prize. }\end{array}$ & 2. & $\begin{array}{l}\text { The child has a brave } \\
\text { mentality. } \\
\text { The child's potential can } \\
\text { develop. } \\
\text { The child's experience } \\
\text { increases. } \\
\text { The child gets many } \\
\text { achievements }\end{array}$ & $\begin{array}{l}\text { 1. The child becomes brave. } \\
\text { 2. The child's ability develops. } \\
\text { 3. The child's insight increases. } \\
\text { 4. The child's has lots of friends. } \\
\text { 5. The child gets lots of } \\
\text { achievements. }\end{array}$ \\
\hline $\begin{array}{l}\text { Parents' } \\
\text { responsiveness and } \\
\text { commitment to the } \\
\text { child's multiple } \\
\text { intelligence talents }\end{array}$ & $\begin{array}{l}3 . \\
4 . \\
4 .\end{array}$ & $\begin{array}{l}\text { Making time with the child. } \\
\text { Providing } \\
\text { motivation/support for } \\
\text { the child during the } \\
\text { competition. } \\
\text { Praising and giving rewards. } \\
\text { Facilitating the child's needs }\end{array}$ & $\begin{array}{l}1 . \\
2 .\end{array}$ & $\begin{array}{l}\text { Making time for the child. } \\
\text { Providing } \\
\text { motivation/support for the } \\
\text { child during the } \\
\text { competition. } \\
\text { Praising and giving } \\
\text { rewards. } \\
\text { Facilitating the child's } \\
\text { needs. }\end{array}$ & $\begin{array}{l}\text { Making time for the child. } \\
\text { Providing motivation/support } \\
\text { for the child during the } \\
\text { competition. } \\
\text { Praising and giving rewards. } \\
\text { Facilitating the child's needs. }\end{array}$ \\
\hline
\end{tabular}

Various talents of children multiple intelligences in order to develop and achieve very high abilities highly require balanced demandingness and responsiveness. Demandingness and responsiveness in parenting is a picture of parental support for children's talents. Parental support can promote children's talent (Kiewra, 2014). Parental support is important in developing children's abilities in multiple intelligences. Support provided by parents can foster and build children's confidence. The results of the regression analysis revealed that parental support and involvement positively predicted the academic self-efficacy and self-esteem of children (Ruholt, 2015). A supportive environment can be done by parents to spend time with children, interact pleasantly with children, and support and help children (Morrison, 2015). The involvement of parents in their children's learning process provides many opportunities for success, such as improving morals and attitudes, academic achievement in all fields, as well as social attitudes and adjustments (Sapungan, 2014).

Based on the research data, it can be explained that the parenting pattern for developing multiple intelligences in early childhood is very visible through the forms of demandingness and responsiveness of parents. The demandingness and responsiveness shown by these parents are manifested in the form of treatment and very high concern for the abilities possessed by their children. Forms of parental demandingness include the child's talent must develop, be a brave child, and the child's insight must increase, and obtain many achievements. In addition, parents are very disciplined and strict in educating, training, and directing children's abilities. The responsiveness shown by parents in this parenting are parents who are always eager to take the time to escort and accompany their children in various activities, especially during tutoring and competitions, give encouragement to their children during the competition, and give praise and reward to their children. In addition, what is also important is parents with the totality of facilitating and meeting the equipment and needs of their children, both related to the needs of tutoring and competitions. Thus, it can be understood that demandingness and responsiveness of parents in developing children's multiple intelligences are very much in line with the authoritative style where the demandingness and responsiveness of parents are very high towards children.

\section{Theme 3. The development and stimulation of multiple intelligences}

To develop children's multiple intelligences, the participants used two ways, namely: a) guiding and training children, and b) involving children in various competition activities. First, in guiding and training the abilities of these children there are some differences between one another. R1 and R3 train children's abilities by taking them to join courses according to their interests and talents. Motivation to involve their children in courses is one of ways so that their children's talents develop. R1 gave the following statement:

My motivation to take my child to join courses is to train and develop his talents. He has talent. If I don't take him to join courses, his talent won't develop. In addition, I am also not able to train him (R1).

In line with that, R3 said:

The reason I take my child to take courses is to gain insights and experiences so that his potential can develop. In addition, that's why my child gets many friends and does not become timid (R3).

According to R1's explanation, there were many lessons attended by her child, including singing, dancing, fashion shows, and Jarimatika. The lessons attended by R3's child include coloring, Jarimatika, and English. 
$\mathrm{R} 2$ in guiding and training her child is able to do it independently. In other words, the child is not enrolled in courses like the children of other participants. The reasons for not taking her child in courses are the location of her house is too far from the place of tutoring and there is limited time to take and pick up during courses. She gave the following statement:

I do not take my child to take courses because we cannot find one here. It takes time to go to the city and it is also costly. In addition, my husband and I find it difficult to allocate time to take and pick him up during courses, because we both work (R2).

Therefore, R2 often self-train and guide her child at home where she learns through YouTube and searches for information and material for children through google. Secondly, with regard to the involvement of various competition activities, all participants have things in common. That is, the participants always include various competitions to determine the ability of children. R1 gave the following statement:

Almost every week I always take my child to join competition. Sometimes in one day, I can take him to 2 - 3 competitions. This aims to train the child's courage to appear in public and measure the child's ability. However, today's purposes are to win, get trophies, and money. When winning the competition, he is happy for getting more trophies (R1).

In line with R1, R2 and R3 also revealed the same thing:

Initially, I took my children to participate in competition so he would take some lessons. Although at that time he never won. But now it intends to get experience of children and to train his abilities (R2).

I often take my child to join competition so that his abilities develop. Then, his mental and creativity continue to grow. Besides, he will be able to add relationships and experience (R3).

Based on this explanation, it can be understood that the methods used by parents in developing children's multiple intelligences include 1) guiding and training children, both independently and by taking courses and 2) involving children to join various competition activities. The methods used in the development of children's multiple intelligences can be seen in table 3 .

Those are some parenting experiences carried out by the participants in developing multiple intelligences of early childhood. Although there are some differences, in general there are many similarities, both in terms of identification, demandingness and responsiveness, and the methods used.

The development and stimulation of multiple intelligences is very important for early childhood. The first and foremost method in developing intelligence talent is to guide and train children in learning. In guiding and training, these children can be done by their own parents or involve other people or parties. If parents have the ability to guide and train themselves, and there is more time for children, it is very good for children to get them from parents. If parents have limitations, both ability and time, it will be better to involve other parties. The most important thing in this case is the ability or talent of children can be stimulated properly, and therefore they can develop optimally. Parke and Buriel believe that parents fulfill the expected role and socialize children in three ways, namely: (1) as a child interactive partner, (2) as a direct instructor, and (3) as a provider of activities and opportunities that stimulate children's growth (Brooks, 2011). According to Parke and Buriel, it can be understood that parents in guiding and training the ability of these children can act as partners, instructors or direct trainers or simply facilitate and provide activities to develop children's abilities.

According to Vygotsky's view every child has a zone of proximal development (ZPD), which is the distance between the potential level of child development and the level of ability the child already has by the child at that time (Salkind, 2004). This zone is intended as the right place and time to improve children's abilities where in increasing these abilities children cannot do it themselves but must need the help of others, such as parents, educators, and peers. The zone of proximal development of children can be maximized by providing assistance and intervention early on. Referring to the Vygotsky's concept, various roles of parents in developing and stimulating multiple intelligences above can be interpreted as scaffolding where the assistance and intervention is given by parents by guiding and training children, either done alone or by involving children in institutions of course or tutoring.

Table 3. Parental methods in developing and stimulating children's multiple intelligences

\begin{tabular}{|c|c|c|c|c|c|c|}
\hline \multirow{2}{*}{$\begin{array}{c}\text { Forms of } \\
\text { Experience }\end{array}$} & \multicolumn{6}{|c|}{ Names of Participants } \\
\hline & & R1 & & R2 & & R3 \\
\hline $\begin{array}{c}\text { Methods of } \\
\text { developing } \\
\text { children's multiple } \\
\text { intelligences }\end{array}$ & 1. & $\begin{array}{l}\text { Taking the child to take } \\
\text { courses. } \\
\text { Participating in } \\
\text { competition. }\end{array}$ & 1. & $\begin{array}{l}\text { Guiding and training } \\
\text { independently. } \\
\text { Participating in competition. }\end{array}$ & $\begin{array}{l}1 . \\
2 .\end{array}$ & $\begin{array}{l}\text { Taking children to join } \\
\text { courses. } \\
\text { Participating in competition. }\end{array}$ \\
\hline
\end{tabular}


The second method used by parents in developing their children's abilities is to join a competition. This competition is intended to give children the opportunity to measure children's abilities with others. Through this competition, children can get a lot of experience, motivation, and train the mental or courage of children to continue to excel. The competition has several advantages, namely helping children develop healthy attitudes about winning and losing, improving, training, and increasing children's abilities, and encouraging children to excel (Johnson, 1993). The constructive competition can motivate children to perform even better. Competition is a form of motivation that can be a significant driver of learning. By following competition children can get many benefits, including: being able to know their abilities and limitations, set goals, overcome defeat, develop skills, increase popularity, develop competencies in an area, practice problem solving, try various roles, learn various rules of the game, and work with others (Johnson, 1993).

These various explanations provide understanding that taking the children to the competition can provide a positive impact on their lives. However, taking children to join competition actually also has a negative impact on children. One of them is that it can lead to mental and emotional disturbance of children, and sometimes the competition is done only for the benefit of parents (Johnson, 1993). Therefore, to reduce the negative impact on children, parents must be wise in involving children in various competitions. Parents must accept whatever results the child receives without having to punish and disappoint the child. Make the competition as a learning material for children.

Based on the results and discussion of parenting experiences, a parenting pattern can be developed to develop multiple intelligences in early childhood. This parenting pattern consists of identifying the interests and talents of children, the demandingness and responsiveness of parents, as well as development and stimulation of multiple intelligences. This pattern of parenting can make the optimal intelligence of a child develop and get high achievement. Forms of achievement that can be achieved by these children can be cognitive, affective, and psychomotor. The cognitive domain emphasizes the development of children's intellectual abilities and skills from the simplest to the most complex, the psychomotor relating to educational goals related to activities that require nerve and muscle coordination, and the affective relating to educational goals related to the development of feelings, value systems, emotions and attitudes (Soenarjo, 2014).

The parenting pattern that the researchers produced from this research is shaped like a house building, where there are foundations, support poles, and roofs of houses. This is based on the philosophy that a home building will stand firm and look beautiful if it has these three things. The foundation is a picture of the initial abilities possessed by each child. In other words, every child basically has all the multiple intelligences. The supporting pole is a picture of the parenting process that parents do where the parenting serves as scaffolding to maximize the ability of children. The roof of the house is a picture of the achievement of children's abilities. This means that a strong foundation and sturdy support poles will be able to support a desired roof. Each part is a unity and mutually reinforces one another. The form of the concept can be seen in Figure 1.

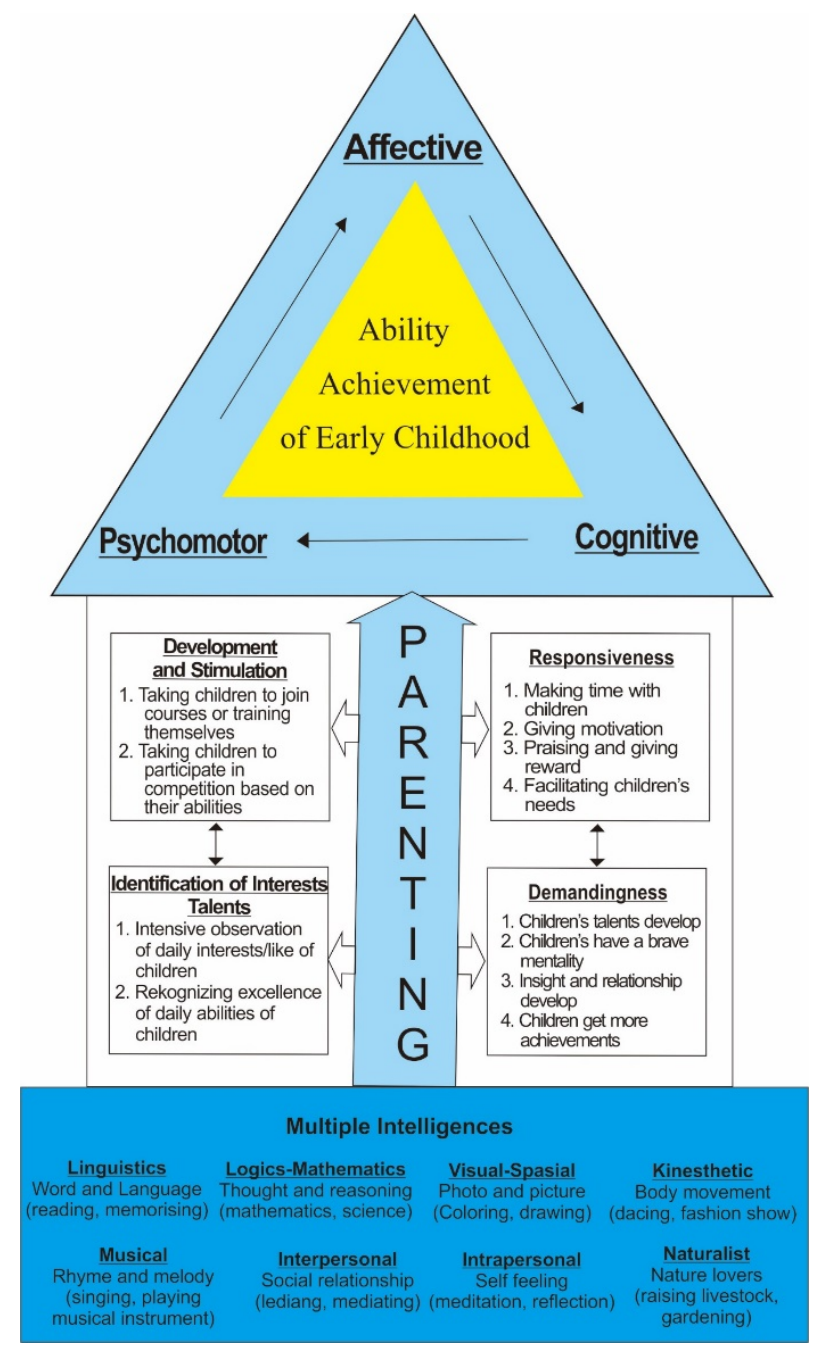

Figure 1. The concept of parenting patterns for developing multiple intelligences in early childhood.

\section{Conclusions}

Parents have an important role in developing multiple intelligences in early childhood. Parenting style that is used by parents really determines success in stimulating children's intelligence. From this research, it can be understood that the appropriate parenting style used by parents is authoritative where parents not only demand children excessively, but also support and facilitate the child's needs well. In other words, if you want a child's 
multiple intelligences to develop properly, then the demandingness and responsiveness must be balanced. The right parenting pattern can make children reach their highest abilities and therefore they can achieve many achievements, both in the cognitive, psychomotor, and affective domains.

\section{Research Limitations}

In the aspect of applying this research methodology that should have been carried out with full active participation in the daily lives of the informants, the researcher could not yet do it fully. This is due to the busyness and activity of each family member that is not possible for researchers to intervene. In addition, the development of multiple intelligences is only limited to children aged 4-8 years.

\section{Acknowledgments}

On this occasion, the researcher thanked the Education Fund Management Institute (LPDP), the Ministry of Finance of the Republic of Indonesia that has been willing to grant the overall cost of this research. Thanks also to Universitas Muhammadiyah Ponorogo that has provided research facilities and infrastructure. I also thank the resource persons who have helped in the process of extracting the research data.

\section{REFERENCES}

[1] Agustin, M. (2013). Recognize and develop the potential for multiple children's intelligence early on as an early milestone giving birth to a golden generation. Jurnal Cakrawala Dini, 4(2), 113-122. Retrieved from https://ejournal.upi.edu/index.php/cakrawaladini/article/vie w/10390/6434

[2] Arsmtrong, T. (2009). Multiple intelligences in the classroom ( $3 \mathrm{rd}$ ). America: the Association for Supervision and Curriculum Development (ASCD) Alexandria.

[3] Baumrind, D. (1966). Effects of Authoritative Parental Control on Child Behavior. Child Development, 37(4), 887. https://doi.org/10.2307/1126611

[4] Baumrind, D. (1991). The influence of parenting style on adolescent competence and substance use. The Journal of Early Adolescence, 11(1), 56-95.https://doi.org/10.1177/02 72431691111004

[5] Baumrind, D. (2005). Patterns of parental authority and adolescent autonomy. New Directions for Child and Adolescent Development, 108, 61-69.https://doi.org/10.100 2/cd.128

[6] Baumrind, D. (2010). Effects of Preschool Parents' Power Assertive Patterns and Practices on Adolescent Development. Parenting, 10(3), 157-201.https://doi.org/10

\section{$.1080 / 15295190903290790$}

[7] Berns, R. M. (2010). Child, family, school, community: Socialization and support (Eighth Edi). USA: Wadsworth Cengange Learning.

[8] Bogdan, R. (1982). Qualitative research for education: an introduction to theory and methods. Boston: Allyn and Bacon, Inc.

[9] Brooks, J. (2011). The process of parenting (Eight edit). New York: Imprint of The McGraw-Hill, Inc.

[10] Chatib, M. (2016). Man's parents: Skyrocketing potential and intelligence by respecting the nature of each child. Bandung: Kaifa.

[11] Creswell, J. W. (2008). Educational research: planning, conducting, and evaluating quantitative and qualitative research. New Jersey: Person Educational, Inc.

[12] Dehyadegary, E. (2012). Relationship between parenting style and academic achievement among iranian adolescents in Sirjan. Asian Social Science, 8(1), 156-160. https://doi.org/10.5539/ass.v8n1p156

[13] Dexter, C. A. (2014). A preliminary investigation of the relationship between parenting, parent-child shared reading practices, and child development in low-income families. Journal of Research in Childhood Education, 28(3), 394410. https://doi.org/10.1080/02568543.2014.913278

[14] Gardner, H. (2006). Multiple intelligences. New York: Basic Books.

[15] Hanafin, J. (2014). Multiple intelligences theory, action research and teacher professional development: The irish MI Project. Australian Journal of Teacher Education, 39(4), 126-142. Retrieved from http://dx.doi.org/10.14221/ajte.20 $14 \mathrm{v} 39 \mathrm{n} 4.8$

[16] Hasbiansyah, O. (2008). Phenomenological approach: Introduction to research practice in social science and communication. Mediator: Jurnal Ilmu Komunikasi, 9(1), 163-180. Retrieved from https://ejournal.unisba.ac.id/index .php/mediator/ article/view/1146

[17] Hidalgo, M. F. (2016). Parenting the gifted and talented child: A qualitative inquiry of the perceptions of mothers regarding their unique experiences in raising gifted and talented children. Retrieved from https://digitalcommons.ls u.edu/gradschool_dissertations/4268

[18] Holden, G. W. (2010). Parenting: a dynamic perspektive. California: Sage Publication, Inc.

[19] Johnson, C. E. (1993). Children \& competition. Nort Carolina Cooperative Extension Service, 1-7. Retrieved from https://extension.tennessee.edu/centerforparenting/TipSheet s/Children\%2520and\%2520Competition.pdf

[20] Khoiri, A. (2016, April 14). Most Indonesian children get wrong parenting. CNN Indonesia, p. 1. Retrieved from https://www.cnnindonesia.com/gaya-hidup/2016041320215 1-255-123787/sebagian-besar-anak-indonesia-salah-asuh

[21] Kiewra, K. A. (2014). Seven ways parents help children unleash their talents. Parenting for High Potential, 3(5), 4 6. Retrieved from https://cehs.unl.edu/images/cehs/soar/arti cles/Seven Ways Parent Help Children Unleash Their 
Talents.pdf.

[22] Kordi, A. (2010). Parenting attitude and style and its effect on children's school achievements. International Journal of Psychological Studies, 2(2), 217-222. Retrieved from http://www.ccsenet.org/journal/index.php/ijps/article/view/ 6158

[23] Lestari, S. (2016). Family psychology. Jakarta: Prenadamedia Group.

[24] Li, X. (2017). Parenting styles of chinese families and children's social-emotional and cognitive developmental outcomes. European Early Childhood Education Research Journal, 25(4), 637-650. https://doi.org/https://doi.org/10.1 080/1350293X.2017.1331077

[25] Morawska, A. (2019). Parenting gifted and talented children: Conceptual and empirical foundations. Gifted Child Quarterly, 53(3), 163-173. https://doi.org/10.1177/0016986 209334962

[26] Morrison, G. S. (2008). Fundamentals of early childhood education (5th ed.). Jersey: Pearson Education, Inc.

[27] Morrison, G. S. (2015). Early childhood education today (13th ed.). Boston: Pearson Education, Inc.

[28] Permono, H. (2013). The role of parents in optimizing the growth and development of children to build the character of early childhood. In Seminar Nasional Parenting Universitas Muhammadiyah Surakarta (pp. 34-37). Surakarta. Retrieved from https://publikasiilmiah.ums.ac.id/xmlui/han dle/11617/3994

[29] Ramphele, L. (2017). The importance of identifying your child's gifts and talents. Retrieved November 25, 2019, from http://www.capetalk.co.za/articles/249714/the-importance-o f-identifying-your-child-s-gifts-and-talents

[30] REPUBLIK INDONESIA. The 1945 State Constitution of the Republic of Indonesia, Pub. L. No. 28B, 12 (1945). Indonesia.

[31] REPUBLIK INDONESIA. Law Number 23 of 2002 concerning child protection (2002). Indonesia.
[32] Ruholt, R. E. (2015). Is parental support or parental involvement more important for adolescents? Undergraduate Journal of Psychology, 28(1), 1-8. Retrieved from https://journals.uncc.edu/ujop/article/view/2 92

[33] Salkind, N. J. (2004). An introduction to theories of human development. New Delhi: Sage Publication, Inc.

[34] Santrock, J. W. (2009). Children (11th ed.). New York: McGraw-Hill.

[35] Sapungan, G. M. (2014). Parental involvement in child's education: Importance, barriers and benefits. Asian Journal of Management Sciences \& Education, 3(2), 42-48. Retrieved fromhttps://www.researchgate.net/publication/28 3539737_Parental_Involvement_in_Child's_Education_Im portance_Barriers_and_Benefits

[36] Sasongko, J. P. (2015, September 16). KPAI: Kekerasan anak dipicu buruknya pengasuhan orang tua. CNN Indonesia, p. 1. Retrieved from https://www.cnnindonesia.com/nasion al/20150916103500-20-79056/kpai-kekerasan-anak-dipicuburuknya-pengasuhan-orang-tua

[37] Soenarjo, F. (2014). Taxonomy of instructional objectives. In Modul pelatihan pengembangan keterampilan dasar teknik instruksional (Pekerti) (pp. 160-175). Surabaya: Kopertis VII.

[38] Sugiyono. (2011). Metode penelitian kuantitatif, kualitatif, dan $R \& D$. Bandung: Alfabeta.

[39] Sulistyawati, L. (2018, March 26). KPAI: 16 children died as a result of violence in 2018. Republika, p. 1. Retrieved from https://m.republika.co.id/berita/nasional/hukum/18/03/26/p 66zma409-kpai-16-anak-meninggal-akibat-kekerasan-pada2018

[40] Tiel, J. M. van. (2015). Detection and handling of gifted children. Jakarta: Prenadamedia Group.

[41] UNESCO. (2017). Early childhood care and education. Retrieved January 25, 2018, from https://en.unesco.org/the mes/early-childhood-care-and-education 